(C) 1980. The Genetical Society of Great Britain

\title{
ALLOZYME VARIATION ACROSS A NARROW HYBRID ZONE IN THE GRASSHOPPER, CALEDIA CAPTIVA
}

\author{
CHRIS MORAN*†, PATRICIA WILKINSON* and DAVID D. SHAW* \\ *Department of Population Biology, Research School of Biological Sciences, Australian National \\ University, Canberra, A.C.T. 2601; †Department of Genetics, University of Melbourne, Parkville, \\ Victorio 3052
}

Received 6.vii.79

\section{SUMMARY}

Seventeen enzyme systems comprising 23 genetic loci were assayed in the Moreton and Torresian chromosomal taxa of Caledia captiva and an assessment was made of the allelic variation within and between these taxa. Heterozygosity per individual in both taxa averaged 10-12 per cent. Nei's coefficient of genetic distance between the two taxa was calculated to be $0 \cdot 158 \pm 0.061$.

Five of the 23 loci showed large differences in frequency between the taxa. ME showed a difference of 50 per cent in allelic frequency, whereas GOT-2, GPT, ICDH-1 and PGI showed differences in frequencies of 90 per cent or greater. Alleles at these loci were characteristic if not absolutely diagnostic of the races.

These five enzyme loci provided additional markers for the analysis of samples taken across a transect of the hybrid zone and revealed that the major change in frequency for all loci occurred over a 200 metre interval, which coincided with the location of the major change in chromosomal frequency. However, no gametic disequilibrium between the four characteristic loci could be detected in the central populations of the hybrid zone, implying that these loci, at least, could freely segregate and recombine in hybrids and backcrosses.

The highly symmetrical pattern of replacement for these loci contrasts markedly with the very asymmetrical pattern of chromosomal replacement, with high levels of one-way introgression of chromosomes from the Torresian into the Moreton race. Further, the detection of characteristic Moreton alleles, at frequencies of up to 20 per cent, in Torresian populations which contained a very low frequency of introgressed Moreton chromosomes, emphasises that a large proportion of the genome remains undefined and unrecognisable when the hybrid zone is assessed by chromosomal rearrangements alone.

\section{INTRODUCTION}

NARRow hybrid zones between closely related taxa have been recognised after analysis of morphological (Yang and Selander, 1968) chromosomal (White et al., 1969; Hall and Selander, 1973; Hewitt, 1975; Moran, 1979), genic (Hunt and Selander, 1973; Duncan and Highton, 1979) or behavioural criteria (Littlejohn and Watson, 1976). In only a few cases, however, has a combination of these criteria been applied. For example, McDonnell, Gartside and Littlejohn (1978) compared and contrasted the patterns of replacement of morphological and genic characters, in addition to measuring genetic incompatibility, across the hybrid zone in Pseudophryne. In this and an accompanying paper (Shaw et al., in prep.), the patterns of both chromosomal and genic replacement and introgression across the hybrid zone are analysed and compared in the Acridine grasshopper, Caledia captiva. 
The Moreton and Torresian races of Caledia captiva have clearly distinguishable chromosome complements (Shaw, 1976; Shaw et al., 1976; Moran and Shaw, 1977). Despite the very large number of chromosomal differences involving most of the genome, the external phenotype of the two taxa remains very similar, so that neither of the two parental types (Moran, 1978) nor the hybrids between them can be recognised on morphological criteria. Because of the highly asymmetrical pattern of chromosomal introgression across the hybrid zone (Moran and Shaw, 1977), an electrophoretic analysis of genic variation within and between the races was carried out in order to obtain further markers for the analysis of the structure of the hybrid zone and the interactions which occur between the taxa in the contact zone. Fortunately both chromosomal and genic information can be obtained from the same individuals, permitting a very detailed comparison to be made. This paper is restricted to a description of the genic variation and differentiation and a discussion of the consequences that this information has on the interpretation of hybrid zones.

\section{MAterials AND MEthods}

(i) Sampling

Samples of adult grasshoppers were collected from seven locations in south-east Queensland during July 1978 (Transect 2 of Moran, 1979). An additional sample was taken close to the coast in 1979. The sampling localities were:

1. Bongmuller-this population had been sampled in 1976 for chromosomal analysis. The karyotypes of all individuals consists of acrocentric-telocentric chromosomes which is characteristic of the Torresian race (Shaw, 1976; Moran and Shaw, 1977).

2. Bell's Bridge-a population located $16 \mathrm{~km}$ east of Bongmuller and $1.5 \mathrm{~km}$ west of the Mary River. This Torresian population contains a very low frequency of introgressed, metacentric, Moreton chromosomes.

3. MRl-MR4-a $200 \mathrm{~m}$ interval transect to the east of the Mary River (fig. 1). It was known that the transition between the Torresian and Moreton chromosomal taxa occurred in this very narrow region, although it had not been accurately defined (Moran, 1979).

4. Spring Valley Creek-approximately $1 \mathrm{~km}$ south-east of the Mary River 4 sampling site. This population has also been analysed chromosomally over 3 years and displays a high level of chromosomal polymorphism (Shaw et al., in prep.).

5. Peregian Beach-this sample was collected in 1979 and includes some individuals from Bribie Island. It is situated about $68 \mathrm{~km}$ south-east of the Spring Valley Creek population and was chosen for isozyme analysis because of the very low frequency of acro- and telocentric chromosomes (see Moran and Shaw, 1977). This population represents a pure Moreton control for assessing genic introgression in contact zone populations at Spring Valley Creek.

The population samples were transported to the laboratory, where they were individually coded and injected with $0.5 \mathrm{ml}$ of 0.05 per cent colchicine in insect saline. After 6 hours, the mid-gut caeca were removed and fixed 


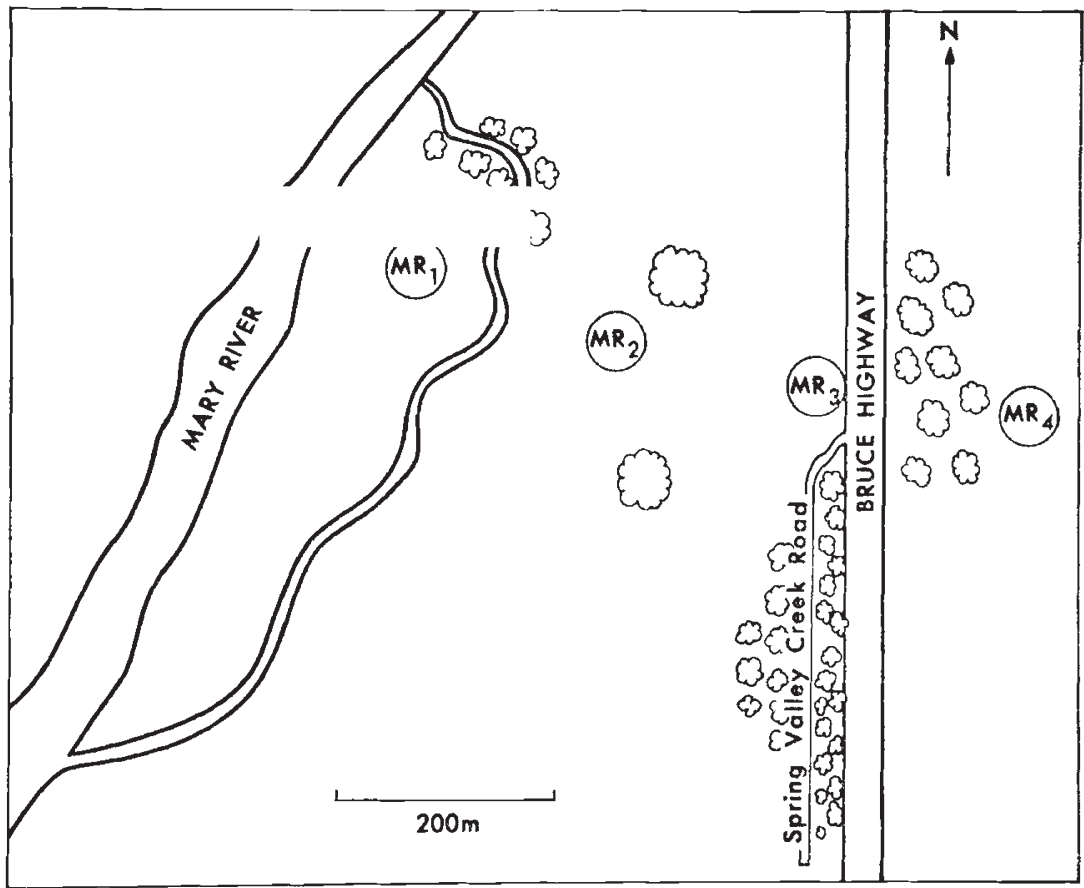

Frg. 1.-Site map of the 200 metre interval collections across Transect 2. Both chromosomal and electrophoretic data were collected from these samples. (The location of the transect corresponds to the Transect 2, fig. 1 of Moran (1979).)

in $3: 1$ absolute ethanol : glacial acetic acid. This tissue was stored at $5^{\circ} \mathrm{C}$ prior to chromosome analysis (see Shaw et al., in prep.). The degutted bodies of these grasshoppers were placed in plastic tubes, frozen in liquid nitrogen and stored at $-20^{\circ} \mathrm{C}$ until the enzyme assays were performed. In this way, cross-referencing of chromosomal and electrophoretic data within the same individual was possible.

\section{TABLE 1}

Buffers and running conditions for all enzymes. Almost all enzyme systems were tried with each buffer but the above combinations produced the best resolution and separation. However, it should be noted that some commercial preparations of maleic acid are contaminated with malic acid. Consequently MDH or ME may appear as a nothing dehydrogenase when TEM or TM are used as running buffers. These bands can be minimised by using purer preparations of maleic acid although in this study $M E$ and $I C D H$, and $\alpha-G P D H$ and $M D H$, were deliberately stained on the same gels

Running buffer

Tris EDTA maleate

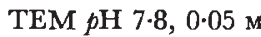

Tris maleate TM $p \mathrm{H} \mathrm{7 \cdot 8,0.05} \mathrm{м}$

Tris EDTA borate TEB $p \mathrm{H} \mathrm{7.8,0.015} \mathrm{M}$

Tris citrate $\mathrm{TC} p \mathrm{H} 7.8$

\begin{tabular}{|c|c|c|}
\hline $\begin{array}{l}\text { Current } \\
(\mathrm{mA} / \mathrm{gel})\end{array}$ & $\begin{array}{l}\text { Time } \\
\text { (hrs) }\end{array}$ & Enzyme system \\
\hline 8 & $1 \frac{1}{2}-1 \frac{3}{4}$ & $\begin{array}{l}\text { ME, ICDH, } \alpha-G P D H, \text { Amy } \\
\text { MDH, HK, DIA, Ald, HBDH, Acph }\end{array}$ \\
\hline $4-5$ & 2 & PGI \\
\hline 3 & $1 \frac{1}{2}$ & $\begin{array}{l}\text { G3PDH, Fum, PGM } \\
\text { 3PGK }\end{array}$ \\
\hline $7-8$ & $1 \frac{1}{2}$ & GOT, GPT \\
\hline
\end{tabular}




\section{(ii) Allozyme analysis}

All electrophoretic assays were performed within 3 months of the collection date. As required, a tissue sample was prepared for each individual by thoroughly homogenising the head in $0.25 \mathrm{ml}$ of extraction solution $(100 \mathrm{ml}$ of distilled $\mathrm{H}_{2} \mathrm{O}$ containing $1 \mathrm{ml}$ of neutralised 10 per cent disodium EDTA, $50 \mu \mathrm{l} \beta$-mercaptoethanol and $0.5 \mathrm{ml}$ of $2 \mathrm{~mm} \mathrm{NADP}$ ). The homogenate was centrifuged and the clear supernatant used for all assays. Cellogel (Chemetron, Milan) was used as the electrophoretic medium.

For positive staining systems, the gels were dipped in $1 \mathrm{ml}$ of staining solution. They were then lightly blotted to remove excess fluid and incubated in a humid light-proof chamber at room temperature. For negative staining systems, the gels were incubated and then dipped in a dye solution to stain the background of the gel. (See Appendix for detailed staining procedures.)

\section{Results}

(i) Gene frequencies

The complete gene frequency data for all populations are summarised in table 2. Of the 23 loci scored, seven were invariant and identical in both taxa of Caledia. A further eight loci showed negligible to low levels of variation (from MDH-1 to HBDH in table 2). Two loci, those for HK-2 and

TABLE 2

Gene frequency data. Alleles have been designated from a-e, from the fastest to the slowest. In all cases, the most common allele has been designated c (alleles originally named for Torresian data). Where two isozymic loci appear for a particular enzyme system, such as $M D H$, the more anodally migrating locus is given the suffix 1 , and the slower migrating locus is given the suffix 2. For some invariant loci, such as $3 P G K$ and Acph, data have not been collected from all populations for reasons of economy. Likewise, for the Peregian samples, only the inter-taxon variant systems have been examined. The homozygosity ( $\mathrm{j}$ ) has also been presented for each locus. The sample sizes below the site names refer to the number of specimens examined

\begin{tabular}{|c|c|c|c|c|c|c|c|c|c|}
\hline & & $\begin{array}{l}\text { Bong- } \\
\text { muller } \\
(31)\end{array}$ & $\begin{array}{c}\text { Bell's } \\
\text { Bridge } \\
(35)\end{array}$ & $\begin{array}{r}\text { MR1 } \\
(13)\end{array}$ & $\begin{array}{c}\text { MR2 } \\
(25)\end{array}$ & $\begin{array}{c}\text { MR3 } \\
(34)\end{array}$ & $\begin{array}{c}\text { MR4 } \\
(11)\end{array}$ & $\begin{array}{c}\text { Spring } \\
\text { Valley } \\
\text { Creek } \\
(35)\end{array}$ & $\begin{array}{l}\text { Pere- } \\
\text { gian } \\
(53)\end{array}$ \\
\hline $\begin{array}{l}\text { 3PGK, Acph, } \\
\text { Fum, Ald, } \\
\text { G3PDH }\end{array}$ & $\begin{array}{l}c \\
\mathrm{j}\end{array}$ & $\begin{array}{l}1 \cdot 0 \\
1 \cdot 0\end{array}$ & $\begin{array}{l}1.0 \\
1.0\end{array}$ & - & - & - & - & $\begin{array}{l}1.0 \\
1.0\end{array}$ & - \\
\hline$\alpha$-GDPH, DIA-2 & $\begin{array}{l}c \\
\mathrm{j}\end{array}$ & $\begin{array}{l}1.0 \\
1.0\end{array}$ & $\begin{array}{l}1 \cdot 0 \\
1 \cdot 0\end{array}$ & $\begin{array}{l}1.0 \\
1.0\end{array}$ & $\begin{array}{l}1.0 \\
1.0\end{array}$ & $\begin{array}{l}1.0 \\
1.0\end{array}$ & $\begin{array}{l}1 \cdot 0 \\
1 \cdot 0\end{array}$ & $\begin{array}{l}1.0 \\
1.0\end{array}$ & - \\
\hline MDH-1 & $\begin{array}{l}b \\
c \\
d \\
\mathrm{j}\end{array}$ & $\begin{array}{l}0.01 \\
0 \cdot 99 \\
- \\
0 \cdot 97\end{array}$ & $\begin{array}{l}0 \cdot 01 \\
0 \cdot 98 \\
0 \cdot 01 \\
0 \cdot 94\end{array}$ & $\frac{\overline{1} \cdot 0}{1 \cdot 0}$ & $\begin{array}{c}0.02 \\
0.98 \\
- \\
0.96\end{array}$ & $\begin{array}{c}0.01 \\
0.99 \\
- \\
0.97\end{array}$ & $\begin{array}{l}0.05 \\
0.95 \\
-\overline{0} \\
0.91\end{array}$ & $\begin{array}{l}0.01 \\
0.99 \\
-\overline{0.97}\end{array}$ & $\begin{array}{l}- \\
- \\
-\end{array}$ \\
\hline MDH-2 & $\begin{array}{l}c \\
d \\
\mathrm{j}\end{array}$ & $\frac{1 \cdot 0}{1 \cdot 0}$ & $\frac{1.0}{1 \cdot 0}$ & $\frac{1 \cdot 0}{1 \cdot 0}$ & $\frac{1 \cdot 0}{1 \cdot 0}$ & $\frac{1 \cdot 0}{1 \cdot 0}$ & $\frac{1 \cdot 0}{1 \cdot 0}$ & $\begin{array}{l}0 \cdot 96 \\
0 \cdot 04 \\
0 \cdot 91\end{array}$ & E \\
\hline ICDH-2 & $\begin{array}{l}c \\
d \\
\mathrm{j}\end{array}$ & $\frac{1 \cdot 0}{1 \cdot 0}$ & $\frac{1 \cdot 0}{1 \cdot 0}$ & $\frac{1 \cdot 0}{1 \cdot 0}$ & $\frac{1 \cdot 0}{1 \cdot 0}$ & $\frac{1 \cdot 0}{1 \cdot 0}$ & $\frac{1 \cdot 0}{1 \cdot 0}$ & $\begin{array}{l}0 \cdot 99 \\
0 \cdot 01 \\
0 \cdot 97\end{array}$ & $\frac{1 \cdot 0}{1 \cdot 0}$ \\
\hline HK-1 & $\begin{array}{l}b \\
c \\
\mathrm{j}\end{array}$ & $\begin{array}{l}0.03 \\
0.97 \\
0.94\end{array}$ & $\begin{array}{l}\overline{1 \cdot 0} \\
1 \cdot 0\end{array}$ & $\begin{array}{l}0.08 \\
0.92 \\
0.85\end{array}$ & $\begin{array}{l}\overrightarrow{1 \cdot 0} \\
1 \cdot 0\end{array}$ & $\begin{array}{l}\overline{1 \cdot 0} \\
1 \cdot 0\end{array}$ & $\begin{array}{l}0.05 \\
0.95 \\
0.91\end{array}$ & $\begin{array}{l}0 \cdot 04 \\
0.96 \\
0 \cdot 91\end{array}$ & - \\
\hline
\end{tabular}


TABLE 2 (continued)

\begin{tabular}{|c|c|c|c|c|c|c|c|c|c|}
\hline & & $\begin{array}{l}\text { Bong- } \\
\text { muller } \\
(31)\end{array}$ & $\begin{array}{c}\text { Bell's } \\
\text { Bridge } \\
(35)\end{array}$ & $\begin{array}{c}\text { MR1 } \\
\text { (13) }\end{array}$ & $\begin{array}{c}\text { MR2 } \\
(25)\end{array}$ & $\begin{array}{c}\text { MR3 } \\
(34)\end{array}$ & $\begin{array}{l}\text { MR4 } \\
\text { (11) }\end{array}$ & $\begin{array}{c}\text { Spring } \\
\text { Valley } \\
\text { Creek } \\
(35)\end{array}$ & $\begin{array}{l}\text { Pere- } \\
\text { gian } \\
(53)\end{array}$ \\
\hline GOT-1 & $\begin{array}{l}b \\
c \\
d \\
\mathrm{j}\end{array}$ & $\begin{array}{c}0.14 \\
0.86 \\
-- \\
0.78\end{array}$ & $\begin{array}{c}0.19 \\
0.81 \\
\overline{0} .78\end{array}$ & $\begin{array}{c}0.08 \\
0.92 \\
\overline{0} \\
0.85\end{array}$ & $\begin{array}{c}0.07 \\
0.93 \\
- \\
0.87\end{array}$ & $\begin{array}{c}0.094 \\
0.906 \\
\overline{0.94}\end{array}$ & $\frac{\overline{1.0}}{1 \cdot 0}$ & $\begin{array}{l}0 \cdot 03 \\
0.90 \\
0 \cdot 07 \\
0 \cdot 80\end{array}$ & $\frac{\overline{1 \cdot 00}}{\overrightarrow{1 \cdot 0}}$ \\
\hline AMY-1 & $\begin{array}{l}b \\
c \\
\mathrm{j}\end{array}$ & $\begin{array}{l}0.06 \\
0.94 \\
0.88\end{array}$ & $\begin{array}{l}\overline{1 \cdot 0} \\
1.0\end{array}$ & $\begin{array}{l}-\overline{1.0} \\
1.0\end{array}$ & $\begin{array}{l}\overline{1 \cdot 0} \\
1 \cdot 0\end{array}$ & $\begin{array}{l}\overline{1 \cdot 0} \\
1 \cdot 0\end{array}$ & $\begin{array}{l}\overline{1.0} \\
1.0\end{array}$ & $\begin{array}{l}\overline{1 \cdot 0} \\
1 \cdot 0\end{array}$ & - \\
\hline AMY-2 & $\begin{array}{l}b \\
c \\
d \\
\mathrm{j}\end{array}$ & $\frac{\overline{1} \cdot 0}{1 \cdot 0}$ & $\frac{\overline{1 \cdot 0}}{\overline{1 \cdot 0}}$ & $\begin{array}{l}\overline{1 \cdot 0} \\
\overline{1 \cdot 0}\end{array}$ & $\frac{\overline{1 \cdot 0}}{\overline{1 \cdot 0}}$ & $\frac{\overline{1.0}}{\overline{1 \cdot 0}}$ & $\frac{\overline{1 \cdot 0}}{\overline{1 \cdot 0}}$ & $\begin{array}{l}0.02 \\
0.96 \\
0 \cdot 02 \\
0.93\end{array}$ & $\begin{array}{l}- \\
-\end{array}$ \\
\hline $\mathrm{HBDH}$ & $\begin{array}{l}c \\
d \\
\mathrm{j}\end{array}$ & $\frac{1.0}{1.0}$ & $\begin{array}{l}0.96 \\
0.04 \\
0.92\end{array}$ & $\frac{1 \cdot 0}{1 \cdot 0}$ & $\frac{1 \cdot 0}{1 \cdot 0}$ & $\frac{1 \cdot 0}{1 \cdot 0}$ & $\frac{1 \cdot 0}{1 \cdot 0}$ & $\frac{1 \cdot 0}{1 \cdot 0}$ & - \\
\hline HK-2 & $\begin{array}{l}c \\
d \\
\mathrm{j}\end{array}$ & $\begin{array}{l}0.73 \\
0 \cdot 27 \\
0 \cdot 60\end{array}$ & $\begin{array}{l}0.53 \\
0.47 \\
0.50\end{array}$ & $\begin{array}{l}0.68 \\
0.32 \\
0.56\end{array}$ & $\begin{array}{l}0.41 \\
0.59 \\
0.52\end{array}$ & $\begin{array}{l}0.54 \\
0.46 \\
0.50\end{array}$ & $\begin{array}{l}0.52 \\
0.48 \\
0.50\end{array}$ & $\begin{array}{l}0.45 \\
0.55 \\
0.51\end{array}$ & $\begin{array}{l}- \\
-\end{array}$ \\
\hline DIA-1 & $\begin{array}{l}b \\
c \\
d \\
\mathrm{j}\end{array}$ & $\begin{array}{l}0 \cdot 15 \\
0 \cdot 79 \\
0 \cdot 06 \\
0 \cdot 70\end{array}$ & $\begin{array}{l}0.11 \\
0.75 \\
0 \cdot 14 \\
0.50\end{array}$ & $\frac{\overline{1.0}}{1.0}$ & $\frac{\overline{1 \cdot 0}}{\overline{1 \cdot 0}}$ & $\frac{\overline{1} \cdot 0}{1 \cdot 0}$ & $\frac{\overline{1 \cdot 0}}{\overline{1 \cdot 0}}$ & $\begin{array}{l}0 \cdot 15 \\
0 \cdot 76 \\
0 \cdot 09 \\
0 \cdot 71\end{array}$ & $\begin{array}{l}- \\
-\end{array}$ \\
\hline PGM & $\begin{array}{l}a \\
b \\
c \\
d \\
e \\
\mathrm{j}\end{array}$ & $\begin{array}{c}0.02 \\
0.04 \\
0.93 \\
0.01 \\
- \\
0.86\end{array}$ & $\begin{array}{l}-\overline{0.01} \\
0.93 \\
0.06 \\
- \\
0.86\end{array}$ & $\begin{array}{l}- \\
\overline{-} \\
0.96 \\
\overline{0} \\
0.04 \\
0.92\end{array}$ & $\begin{array}{c}- \\
- \\
0.06 \\
0.02 \\
0.02 \\
0.92\end{array}$ & $\begin{array}{c}- \\
0.03 \\
0.97 \\
- \\
- \\
0.94\end{array}$ & $\begin{array}{c}0.05 \\
- \\
0.73 \\
0.22 \\
- \\
0.91\end{array}$ & $\begin{array}{c}-\overline{0 \cdot 13} \\
0 \cdot 74 \\
0 \cdot 13 \\
- \\
0 \cdot 69\end{array}$ & $\begin{array}{c}- \\
0.08 \\
0.92 \\
- \\
- \\
\overline{1.0}\end{array}$ \\
\hline ME & $\begin{array}{l}c \\
d \\
\mathrm{j}\end{array}$ & $\begin{array}{l}0 \cdot 63 \\
0 \cdot 37 \\
0 \cdot 56\end{array}$ & $\begin{array}{l}0.53 \\
0 \cdot 46 \\
0 \cdot 60\end{array}$ & $\begin{array}{l}0 \cdot 62 \\
0 \cdot 38 \\
0 \cdot 38\end{array}$ & $\begin{array}{l}0 \cdot 57 \\
0 \cdot 43 \\
0 \cdot 48\end{array}$ & $\begin{array}{l}0.56 \\
0.44 \\
0.53\end{array}$ & $\begin{array}{l}0 \cdot 36 \\
0 \cdot 64 \\
0 \cdot 45\end{array}$ & $\begin{array}{l}0.06 \\
0.94 \\
0.89\end{array}$ & $\begin{array}{l}0.05 \\
0.95 \\
0.90\end{array}$ \\
\hline ICDH-1 & $\begin{array}{l}b \\
c \\
d \\
\mathrm{j}\end{array}$ & $\begin{array}{l}0 \cdot 01 \\
0 \cdot 88 \\
0 \cdot 11 \\
0 \cdot 82\end{array}$ & $\begin{array}{l}-. \\
0 \cdot 77 \\
0 \cdot 23 \\
0 \cdot 60\end{array}$ & $\begin{array}{l}-\overline{0.58} \\
0.42 \\
0.50\end{array}$ & $\begin{array}{l}-\overline{70} \\
0 \cdot 70 \\
0 \cdot 30 \\
0.56\end{array}$ & $\begin{array}{l}-\overline{0.66} \\
0.37 \\
0.56\end{array}$ & $\begin{array}{l}- \\
0.45 \\
0.55 \\
0.64\end{array}$ & $\begin{array}{l}0 \cdot 01 \\
0 \cdot 20 \\
0 \cdot 79 \\
0 \cdot 63\end{array}$ & $\begin{array}{l}- \\
0 \cdot 132 \\
0 \cdot 868 \\
0 \cdot 77\end{array}$ \\
\hline GOT-2 & $\begin{array}{l}a \\
b \\
c \\
\mathbf{j}\end{array}$ & $\begin{array}{l}- \\
0 \cdot 15 \\
0 \cdot 85 \\
0 \cdot 76\end{array}$ & $\begin{array}{l}-\overline{0} \\
0 \cdot 17 \\
0 \cdot 83 \\
0 \cdot 71\end{array}$ & $\begin{array}{l}-\overline{0.23} \\
0 \cdot 77 \\
0.54\end{array}$ & $\begin{array}{l}-\overline{0} \\
0.35 \\
0.65 \\
0.50\end{array}$ & $\begin{array}{l}-\overline{0} \\
0 \cdot 38 \\
0 \cdot 62 \\
0 \cdot 50\end{array}$ & $\begin{array}{l}-\overline{0} \\
0 \cdot 27 \\
0 \cdot 55\end{array}$ & $\begin{array}{l}0.03 \\
0.86 \\
0 \cdot 11 \\
0.77\end{array}$ & $\frac{\overline{1 \cdot 0}}{\overline{1 \cdot 0}}$ \\
\hline GPT & $\begin{array}{l}c \\
d \\
e \\
\mathrm{j}\end{array}$ & $\begin{array}{c}0.92 \\
0.08 \\
- \\
0.90\end{array}$ & $\begin{array}{c}0.79 \\
0 \cdot 21 \\
- \\
0.60\end{array}$ & $\begin{array}{c}0.92 \\
0.08 \\
- \\
0.85\end{array}$ & $\begin{array}{c}0.90 \\
0 \cdot 10 \\
- \\
0.79\end{array}$ & $\begin{array}{c}0.87 \\
0.13 \\
-\overline{0} \\
0.74\end{array}$ & $\begin{array}{l}0 \cdot 14 \\
0 \cdot 82 \\
0 \cdot 04 \\
0 \cdot 64\end{array}$ & $\begin{array}{c}0.16 \\
0.84 \\
- \\
0 \cdot 68\end{array}$ & $\begin{array}{l}- \\
- \\
-\end{array}$ \\
\hline PGI & $\begin{array}{l}a \\
b \\
c \\
d \\
\mathrm{j}\end{array}$ & $\begin{array}{l}0.01 \\
0.03 \\
0.96 \\
\overline{0.91}\end{array}$ & $\begin{array}{l}0.06 \\
0.04 \\
0.90 \\
- \\
0.80\end{array}$ & $\begin{array}{l}0.04 \\
0 \cdot 15 \\
0.81 \\
\overline{0} \\
0.77\end{array}$ & $\begin{array}{l}0 \cdot 02 \\
0 \cdot 11 \\
0 \cdot 85 \\
0 \cdot 02 \\
0 \cdot 70\end{array}$ & $\begin{array}{l}- \\
0 \cdot 12 \\
0 \cdot 87 \\
0 \cdot 01 \\
0 \cdot 74\end{array}$ & $\begin{array}{l}0 \cdot 14 \\
0 \cdot 50 \\
0 \cdot 23 \\
0 \cdot 04 \\
0 \cdot 64\end{array}$ & $\begin{array}{l}0 \cdot 01 \\
0.94 \\
0 \cdot 03 \\
0 \cdot 02 \\
0 \cdot 89\end{array}$ & $\begin{array}{l}-\overline{0} \\
0.88 \\
0.01 \\
0.11 \\
0.79\end{array}$ \\
\hline
\end{tabular}

DIA-1, displayed reasonably high levels of polymorphism in both races. However, there were some technical difficulties in scoring both of these systems and the data collected on them are not as reliable as those presented for other systems. In the case of HK-2, $d d$ homozygotes and $c d$ heterozygotes 
could not be reliably distinguished, so they have been pooled and the gene frequency calculated on the assumption of Hardy-Weinberg equilibrium.

The PGM locus was found to be polymorphic in all populations examined, with five alleles detected. The MR4 and Spring Valley Creek samples have high frequencies of the $d$ allele for this locus, when they are compared with the predominantly Torresian samples and the pure Moreton sample from Peregian.

Malic enzyme (ME) is polymorphic in all Torresian populations which have been examined, with two alleles at intermediate frequencies (see fig. 2). One of these, the $d$ allele, predominates in Moreton populations, although the $c$ variant is found at low frequencies even in the Peregian sample. Given the geographical pattern of polymorphism in both the Torresian and Moreton taxa, it appears that introgression, over more than a kilometre, is not significant at this locus.

Four loci, those for ICDH-1, GOT-2, GPT and PGI, display very large differences in allelic frequency between the two taxa, although none of the alleles can be considered diagnostic (see fig. 2 for illustration of the more common variants of ICDH-1, PGM and PGI). Whether the absence of diagnostic alleles is due to introgression or to low levels of primary polymorphism for these variations cannot be confidently evaluated until both Torresian and Moreton populations further removed from the zone are analysed. In these four cases, and also for $\mathrm{ME}$, the genetic basis of the electrophoretic variation has been established by an examination of laboratory produced $F_{1}$ and backcross hybrids (Shaw and Wilkinson, pers. comm.).

\section{(ii) Heterozygosity and genetic distance}

The level of heterozygosity within, and the differentiation between, the two races of Caledia have been estimated with the proviso that the former may be an overestimate and the latter an underestimate, as a result of introgression into the populations used for these calculations. Further, the $\mathrm{H}$ estimates presented here will tend to be underestimates relative to other published results, as the esterase system was not analysed in this case. The heterozygosity estimates have been calculated for the Bongmuller (Torresian) population and the Spring Valley (Moreton) population. The values are $0.101 \pm 0.028$ and $0.120 \pm 0.031$ respectively, the latter value being higher probably because of the closer proximity of the Spring Valley Creek population to the hybrid zone. Nei's (1972) coefficients of genetic identity and genetic distance have also been calculated using data from the same populations. The coefficient of identity, $I$, is 0.85 and the genetic distance, D, is $0.158 \pm 0.061$ (standard errors for $\mathrm{D}$ and for $\mathrm{H}$ were calculated according to Nei and Roychoudhury (1974)). On this criterion, the two taxa have diverged at least to subspecific level, although the possibility of sibling species status cannot be eliminated (Nei, 1975). A comprehensive electrophoretic analysis of the genus may permit a less equivocal interpretation of this genetic distance estimate in the future.

\section{(iii) Introgression and the pattern of replacement}

The pattern of genic change across the region of contact can be seen in figs. 3 and 4 . The four loci with racially characteristic alleles (figs. 3a, b) 
Plate I

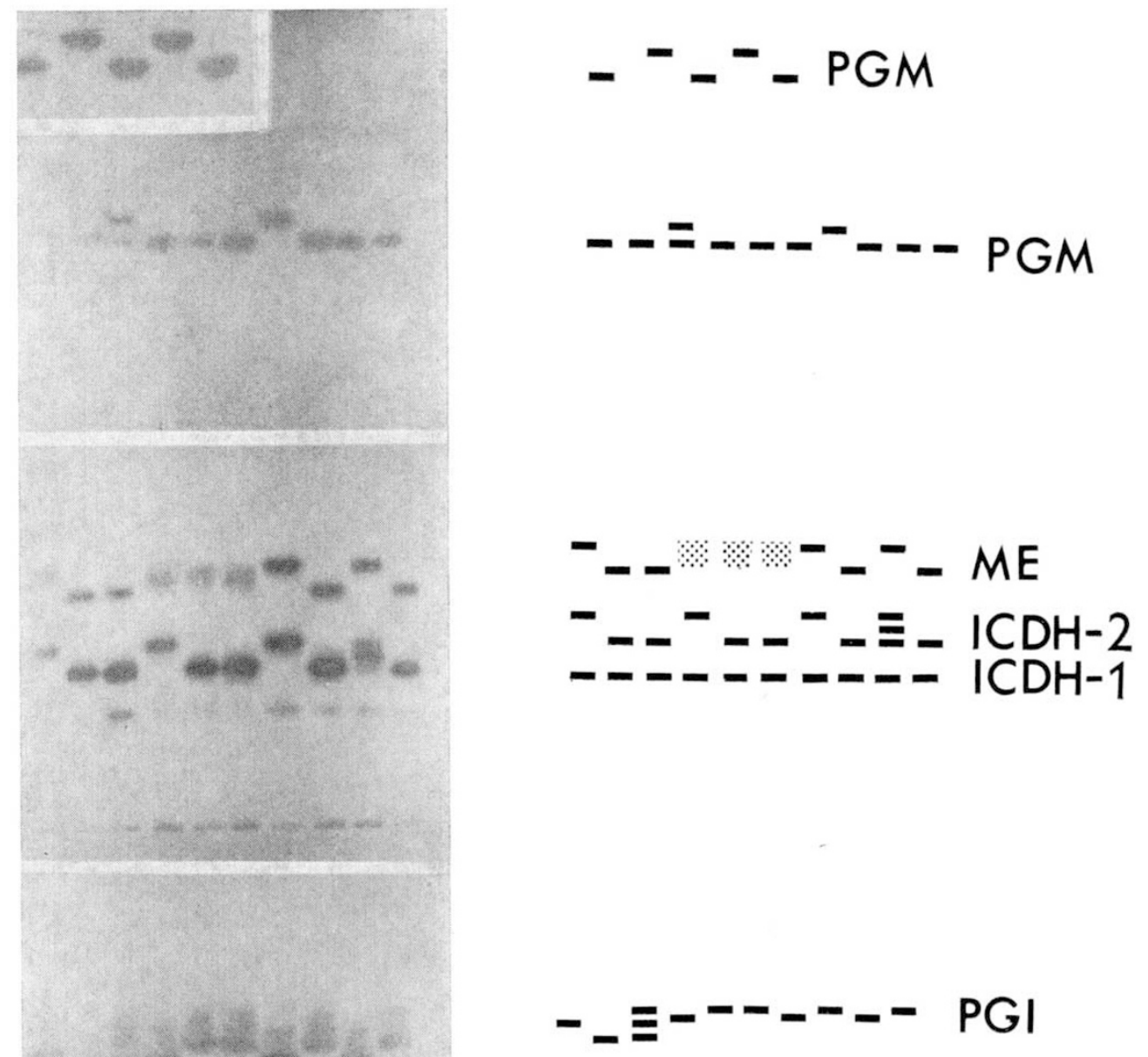

Fig. 2.-Observed allozyme phenotypes for PGM, ME, ICDH, and PGI. It can be seen that PGM is monomeric, as are HKI and 2, Amyl and 2, GOT-1 and DIA-2. Likewise ICDH-1 and PGI are dimeric. It was also established that ICDH-2, MDH-1 and 2 and GOT-2 are dimeric, although they are not illustrated here. ME is clearly multimeric, but the number of polypeptide subunits has not been established. 

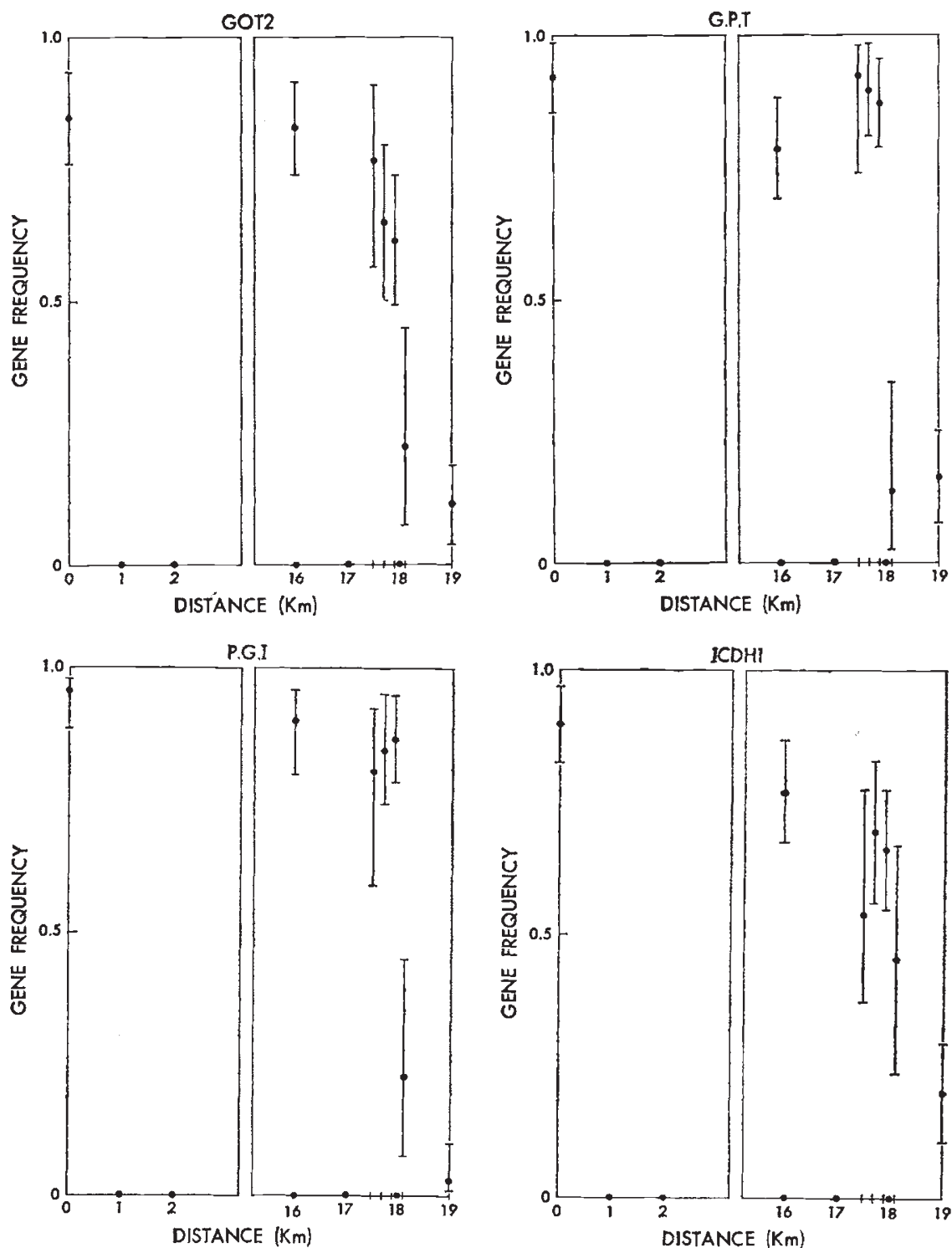

Frg. 3.-Patterns of allelic replacement for enyzmes GOT-2, GPT, PGI and ICDH-1 across the hybrid zone between the Torresian and Moreton taxa of Caledia captiva. The populations are ordered from Bongmuller on the left to Spring Valley Creek on the right, according to table 2. In each case, the frequency of the $c$ allele has been plotted. Ninety-five per cent confidence intervals (Pearson and Hartley, 1954) have been estimated for small samples with skewed frequencies.

show similar and symmetrical changes in frequency across the zone. There are, however, some differences between these loci, for example the PGI and GPT changes are greater and more abrupt than those for ICDH-1 and GOT2 , but in all cases, the mid-points coincide with each other and the tails of the distribution are symmetrical. This is at variance with the pattern of 

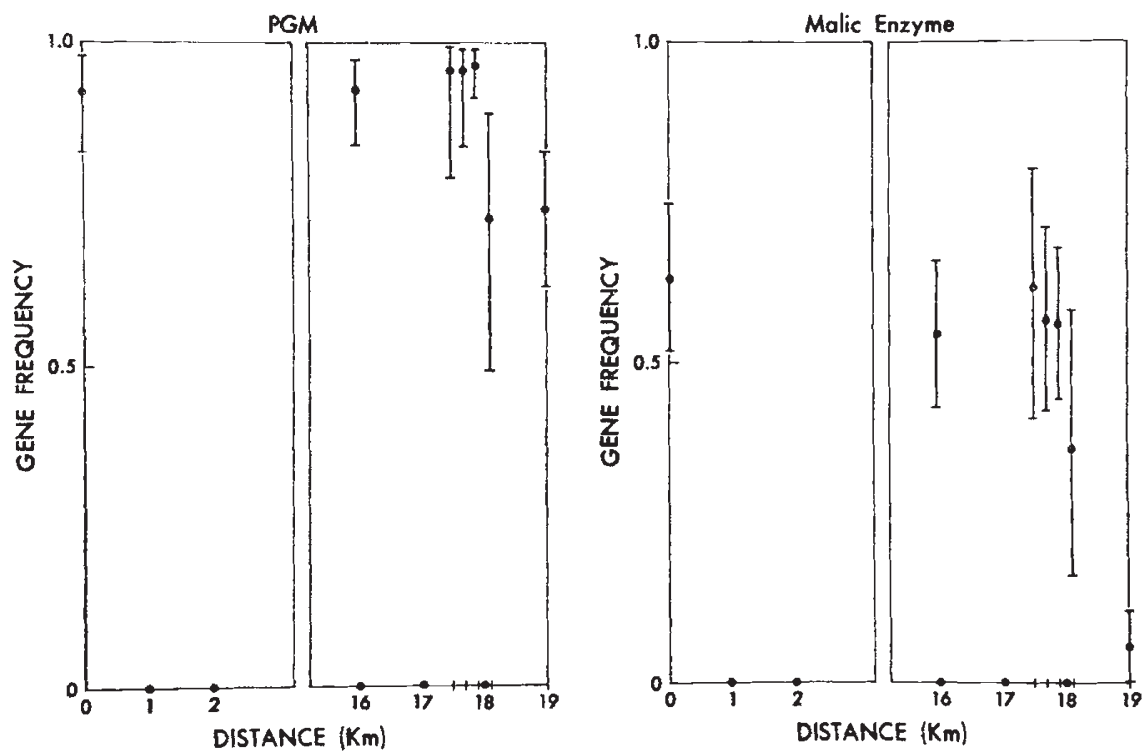

Fig. 4.-Patterns of allelic replacement for enzymes PGM and ME across the hybrid zone between the Torresian and Moreton taxa of Caledia captiva. The populations are ordered as in fig. 3 .

chromosomal change, which is not only highly asymmetrical, but differs significantly between chromosomes and transects (Moran and Shaw, 1977; Shaw et al., in prep.). Further, characteristic Moreton alleles for these loci are found at high frequencies (up to 20 per cent) in the Bell's Bridge population, which is located $2.5 \mathrm{~km}$ from the hybrid zone and is known to contain an extremely low frequency of introgressed Moreton chromosome variants. Thus, even at this level of comparison, the patterns of genic and chromosomal replacement do not correspond.

The magnitude of the frequency changes, their coincidence with the change in chromosomal frequencies and the very small distance over which they occur are remarkable. For PGI and GPT, there are changes of approximately 60 to 70 per cent between MR3 and MR4. Even for ME, there is a difference of 20 per cent although it is not statistically significant. These genic data should be compared with the chromosomal data of Moran (1979) from another transect across the zone, where the major changes in chromosome frequency also occurred over $200 \mathrm{~m}$, a remarkably short distance when one recalls that these grasshoppers are winged and quite capable of prolonged flight.

(iv) Non-random association of non-allelic variants (gametic disequilibrium) in the hybrid zone

Agenic independence test (table 3 ) has been applied to pairwise combinations of the GOT-2, GPT, PGI and ICDH-1 data to determine whether any restraints on segregation or recombination of these markers exist in the hybrid zone. The analysis has been restricted to the MR2 and MR3 data, since it is only in these cases that the sample sizes are sufficiently large and 
the gene frequencies sufficiently intermediate, that such non-random associations can be assessed.

TABLE 3

Two locus genic independence tests for MR2 and MR3. The MR2 $\chi^{2}$ values are in the top right corner of the table and the MR3 results are presented in the lower lefi part of the table. Because of the small sample sizes and skewed gene frequencies, many cell expectations were less than one and were accordingly pooled with a resultant decrease in the number of degrees of freedom (in brackets after the $\chi^{2}$ values). It was also necessary to reduce the PGI data into a two-allele classification. No significant departure from two-locus equilibrium was detected. The close fit of the two-locus data to expectation also indicates that the single-locus data conform to Hardy Weinberg expectations.

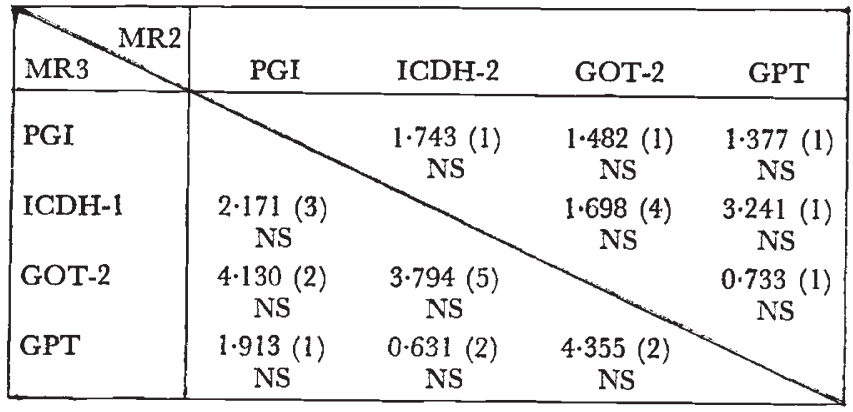

No disequilibria were found between any pair of loci in either of these populations. The fit to expectation was very close in all cases. Thus, alleles at these four loci have been able to segregate or recombine so that they are now statistically independent of each other in the hybrid zone. This independence exists in spite of a demonstrated mechanism of hybrid breakdown which would at least tend to retard the loss of association between non-allelic genes. It must be concluded, therefore, that these electrophoretic genes are not closely linked to the loci responsible for producing hybrid breakdown, or if they are, then the zone has persisted for a sufficient length of time that all such non-random associations have had time to dissipate.

\section{Discussion}

Various hypotheses have been proposed to explain the existence of narrow hybrid zones. They have been summarised and categorised by Moore (1977) as (1) the ephemeral zone hypothesis in which the zone is considered to be a transient prelude to either the fusion of the two taxa or the development of premating isolating mechanisms subsequent to speciation, (2) the dynamic equilibrium hypothesis where hybrids are inferior and (3) the hybrid superiority hypothesis where hybrids are considered to show superior fitness in certain intermediate environments. Moore has chosen the third hypothesis to explain the majority of hybrid zones in vertebrates, maintaining that hybrids are superior in the distinctive environments between the ranges of the parental taxa. The narrowness of the zones is a function of the narrowness of the intermediate ecological conditions or ecotones occupied by the hybrids. While there are some very convincing examples of this, for example in the stickleback Gasterosteus (Hagen, 1967), it is unconvincing as 
a general explanation, even in vertebrates, for the following reasons: the intermediacy and therefore the superiority of the hybrids will be universal only for the first generation of hybrids. Segregation and recombination will ensure that subsequent generations will lose their intermediate character. More important, however, is the perplexing observation that many hybrid zones exist in regions which do not show an abrupt environmental gradient, let alone an ecotone. Clear examples of this are seen in grasshoppers (White et al., 1969; Hewitt, 1975; Moran, 1979), in mammals (Hunt and Selander, 1973; Nevo and Bar-El, 1976), frogs (Littlejohn and Watson, 1976; McDonnell et al., 1978), plants (Bloom, 1976), birds (Burton and Martin, 1976), lizards (Dessauer et al., 1962) and salamanders (Duncan and Highton, 1979). Admittedly, environmental gradients can be found in most areas in which these zones occur. However, the gradients are so gradual and widespread relative to the abrupt morph change in the hybrid zone, that both the parental taxa and the hybrids will share a common environment in the vicinity of the hybrid zone.

These cases clearly require an alternative explanation to the hybrid superiority hypothesis. Given that the zones are persistent, the dynamic equilibrium and the ephemeral zone hypotheses provide easily testable alternatives. In the case of the zone in Caledia, laboratory crosses have shown that $\mathrm{F}_{1}$ hybrids are viable and fertile. However, severe developmental breakdown occurs in the $\mathrm{F}_{2}$ generation (Moran, 1978). A more comprehensive series of crosses (Shaw et al., in prep.) has revealed that the $\mathrm{F}_{2}$ breakdown is absolute and that there is also a complex pattern of hybrid breakdown in the backcross generations. These results clearly demonstrate that a rather complex variant of the dymanic equilibrium hypotheses applies to Caledia.

It is frequently stated that introgression will lead to the ultimate fusion of the taxa involved (Moore, 1977). While not denying this as a possibility (Moran and Shaw, 1977), introgression is only a necessary and not a sufficient condition for fusion. Fusion will not occur if genetic constraints make the process selective (Moran, 1979). Conversely, it has been stated by Hall (1977) that even a very low level of hybrid inferiority will so depress population density in the middle of the zone that there will be a net inward migration of pure parental types. The " hybrid sink" which is created will completely prevent introgression of genetic material across the zone. The chromosomal evidence for selective, asymmetrical in trogression from the Torresian into the Moreton race and the range of penetrance of the introgressed material (Moran and Shaw, 1977) clearly shows that the hybrid sink hypothesis does not apply to Caledia. In fact the above evidence questions the validity of the " hybrid sink" concept, since even the high levels of hybrid breakdown observed in Caledia, which will obviously generate a very high genetic load within the contact zone, are not sufficient to inhibit the introgression of chromosomes across the hybrid zone. The question concerning the effect of the introgressing material upon the fitness of the recipient populations now needs investigation. No direct measurements have yet been made in Caledia but it is known that laboratory populations of Drosophila mojavensis which carry introgressed chromosomes from $D$. arizonensis display superior fitness on a number of criteria when compared with pure parental populations (Nagle and Mettler, 1969). Furthermore, this superior fitness has been shown to result from heterosis involving chromosomes 2 and 3 , 
where the arizonensis forms are retained mainly as heterozygotes (Mettler, 1969). Thus in the case of Caledia the incorporation of foreign chromosomes or chromosome segments is probably indicative of an increased fitness of the recipient taxon. However, when one considers the pattern of introgression in terms of single allozyme alleles, one cannot interpret movement of single alleles in the same way. The observed symmetrical pattern of introgression and the conformation of the data to Hardy-Weinberg expectation (see table 3) suggest that these allozyme variants are effectively neutral as far as their contribution to the structure of the zone is concerned. Their patterns of replacement across the zone are, then, a function of the ease with which they can disassociate themselves by segregation and recombination from the hybrid breakdown mechanism which is maintaining the zone.

If one compares the structure of the Torresian and Moreton chromosomes, then it is seen that up to 40 per cent of the material within chromosomes is involved in the pericentric rearrangements, with a mean value for the entire genome of 22 per cent. The remaining 78 per cent will suffer no structural constraints on recombination in heterozygotes. Therefore one would not expect loci outside the rearrangements to show high levels of linkage disequilibria with the rearrangements unless an independent selective agent was maintaining the association. Assuming a uniform distribution of loci on chromosomes, the a priori probability that four diagnostic loci would be located outside the chromosomal rearrangements is 37.2 per cent. On this basis, it is not surprising to discover introgression of these alleles since they are very likely to be located in the chromosomally undefined parts of the genome.

It is quite clear that hypotheses which invoke simple assumptions to explain the existence and persistence of hybrid zones are untenable. Studies of the genetic basis of hybrid zone structure have to date been minimal and it is only from such investigations that meaningful interpretation will be possible.

Acknowledgments. - We wish to thank David Willcocks for assistance in collecting the insects. Dr Barry Richardson, Department of Population Biology, provided advice on electrophoretic techniques, particularly during the early stages of the project. The preparation of the manuscript benefited from discussions with Drs D. F. Gartside, D. L. Porter and J. Oakeshott. Dr C. Moran wishes to acknowledge receipt of a Temporary Assistantship (A.N.U.) which he held during the course of this work.

\section{REFERENGES}

BLoom, w. L. 1976. Multivariate analysis of the introgressive replacement of Clarkia nitens by Clarkia speciosa polyantha (Onagraceae). Evolution, 30, 412-424.

BURTON, T. C., AND MARTIN, A. A. 1976. Analysis of hybridisation between black-backed and white-backed magpies in south-eastern Australia. The Emu, 76, 30-36.

DESSAUER, H. C., FOX, w., AND POUGH, F. H. 1962. Electrophoresis of transferrins, esterases and other plasma proteins of hybrids between two subspecies of Whiptail lizard (Genus Chemidophorus). Copeia, 1962, 767-774.

DUNCAN, R., AND HIGHTon, R. 1979. Genetic relationships of the Eastern Large Plethodon of the Ouachita Mountains. Copeia, 1979, 95-110.

HAGEN, D. W. 1967. Isolating mechanisms in the threespine sticklebacks (Gasterosteus). 7. Fish. Res. Bd. Canada, 24, 1637-1692.

HALL, w. P. 1977. Cascading chromosomal speciation and the paradoxical role of contact hybridisation as a sink for gene flow. (Submitted to Evolutionary Theory.)

HALL, W. P., AND SELANDER, R. K. 1973. Hybridisation of karyotypically differentiated populations in Sceloporus grammicus complex (Iguanidae). Evolution, 27, 226-242.

$44 / 1-F$ 
HEwITT, G. M. 1975. A sex chromosome hybrid zone in the grasshopper Podisma pedestris (Orthoptera : Acrididae). Heredity, 35, 375-387.

HUNT, w. G., AND SELANDER, R. K. 1973. Biochemical genetics of hybridisation in European house mice. Heredity, 31, 11-33.

LitTLEJOHN, M. J., AND WATsON, G. F. 1976. Mating call structure in a hybrid population of the Geocrinia laevis complex (Anura : Leptodactylidae) over a seven-year period. Evolution, 30, 848-850.

MCDONNELl, L. J., GARTSIDE, D. F., AND LitTlejohn, M. J. 1978. Analysis of a narrow hybrid zone between two species of Pseudophryne (Anura: Leptodactylidae) in south-eastern Australia. Evolution, 32, 602-612.

METTLER, L. E. 1969. Studies on experimental populations of Drosophila arizonensis and Drosophila mojavensis. Univ. Texas Publ. No. 5721, 157-181.

MOORE, w. s. 1977. An evaluation of narrow hybrid zones in vertebrates. Quart. Rev. Biol., 52, 263-277.

MORAN, c. 1978. Population studies of Caledia captiva (Orthoptera : Acridinae) in south-east Queensland. Ph.D. thesis, Australian National University, Canberra, Australia.

MORAN, c. 1979. The structure of the hybrid zone in Caledia captiva. Heredity, 42, 13-33.

MORAN, c., AND SHAw, D. D. 1977. Population cytogenetics of the genus Caledia (Orthoptera : Acridinae). III. Chromosomal polymorphism, racial parapatry and introgression. Chromosoma (Berl.), 63, 181-204.

NAGLE, J. J., AND METTLER, L. E. 1969. Relative fitness of introgressed and parental populations of Drosophila mojavensis and Drosophila arizonensis. Evolution, 23, 519-524.

NEI, M. 1972. Genetic distance between populations. Amer. Nat., 106, 283-292.

NEI, M. 1975. Molecular Population Genetics and Evolution. Elsevier, Amsterdam.

NEI, M., AND ROYCHOUDHuRY, A. K. 1974. Sampling variances of heterozygosity and genetic distance. Genetics, 76, 379-390.

NEVO, E., AND BAR-EL, H. 1976. Hybridisation and speciation in fossorial mole rats. Evolution, 30, 831-840.

PeARson, E. S., AND hartley, H. o. (Editors) 1954. Biometrika Tables for Statisticians, Vol. 1. Cambridge University Press, Cambridge.

SHAw, D. D. 1976. Population cytogenetics of the genus Caledia (Orthoptera : Acridinae). I. Inter- and intraspecific karyotype diversity. Chromosoma (Berl.), 54, 221-243.

SHAW, D. D., WEBB, G. C., AND WILkinson, P. 1976. Population cytogenetics of the genus Caledia (Orthoptera : Acridinae). II. Variation in the pattern of C-banding. Chromosoma (Berl.), 56, 169-190.

SHAW, D. D., WILKINSON, P., AND MORAN, c. Comparison of chromosomal and allozymal variation across a narrow hybrid zone in the grasshopper Caledia captiva. (In prep.)

White, M. J. D., KEY, K. H. L., ANDRÉ, M., AND CHENEY, J. 1969. Cytogenetics of the viatica group of Morabine grasshoppers. II. Kangaroo Island populations. Aust. F. Zool.,17, $313-328$.

YANG, s. Y., AND SELANDER, R. K. 1968. Hybridisation in the grackle Quiscalus quiscala in Louisiana. Syst. Zool., 17, 107-143.

\section{APPENDIX}

\section{Staining procedures}

Acid phosphatase (Acph): $1 \mathrm{ml}$ Tris maleate, $p \mathrm{H} 5.3,0.1 \mathrm{~m} ; 1 \mathrm{mg} \mathrm{Na} \alpha-$ naphthyl acid phosphate; $1 \mathrm{mg}$ Fast Black $\mathrm{K}$ salt. Gel $p \mathrm{H}$ adjusted to 5.3 before staining.

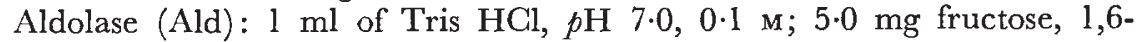
diphosphate; $2 \mathrm{mg} \beta$-NAD + ; $0.2 \mathrm{mg}$ PMS; $0.4 \mathrm{mg}$ MTT; 10 units of glyceraldehyde-3-phosphate dehydrogenase.

Amylase (Amy): Gel incubated at $37^{\circ} \mathrm{C}$ for $\frac{1}{2}$ hour with starch solution containing 1 per cent starch, 0.06 per cent $\mathrm{NaCl}$ in phosphate buffer, $p \mathrm{H} 6 \cdot 5,0 \cdot 1 \mathrm{M}$. This is applied to the gel on a saturated piece of blotting paper. The gel is then rinsed to remove excess starch and is dipped in an iodine solution.

Fumarase (Fum): $1 \mathrm{ml}$ of Tris $\mathrm{HCl}, p \mathrm{H} 7 \cdot 0,0 \cdot 1 \mathrm{M} ; 8 \mathrm{mg}$ fumaric acid 
(sodium salt); $1 \mathrm{mg} \beta$-NAD+; $0.2 \mathrm{mg}$ PMS; $0.4 \mathrm{mg} \mathrm{MTT;} 60$ units malate dehydrogenase.

Glutamate oxaloacetate transaminase (GOT) : $1 \mathrm{ml}$ of Tris $\mathrm{HCl}, p \mathrm{H} \mathrm{7.4,}$ $0.1 \mathrm{~m} ; 5 \mathrm{mg} \mathrm{L}$-aspartic acid; $2.5 \mathrm{mg} \alpha$-ketoglutaric acid; $1 \mathrm{mg} \mathrm{NADH}$; 20 units malate dehydrogenase. Incubate for $10 \mathrm{~min}$. View under U.V. or dip gel in $1 \mathrm{ml}$ buffer containing $0.2 \mathrm{mg}$ PMS; $0.4 \mathrm{mg}$ MTT. Glutamate pyruvate transaminase (GPT): $1 \mathrm{ml}$ of Tris $\mathrm{HCl}, p \mathrm{H} \mathrm{7.4,0.1} \mathrm{m}$; $5 \mathrm{mg}$ L-alanine; $2.5 \mathrm{mg} \alpha$-ketoglutaric acid; $1 \mathrm{mg} \mathrm{NADH}$; 10 units of lactate dehydrogenase. Visualise bands as for GOT.

Glyceraldehyde-3-phosphate dehydrogenase (G3PDH): $1 \mathrm{ml}$ of Tris $\mathrm{HCl}$,

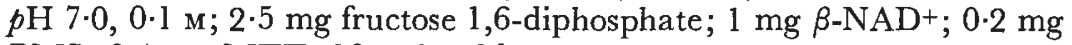
PMS ; 0.4 mg MTT; 10 units aldolase.

$\alpha$-Glycerophosphate dehydrogenase $(\alpha \mathrm{GPDH}): 1 \mathrm{ml}$ of Tris $\mathrm{HCl}, p \mathrm{H} 8 \cdot 6$, $0.1 \mathrm{~m} ; 2.5 \mathrm{mg} \alpha$-glycerophosphate ( $\mathrm{Na}$ salt); $1 \mathrm{mg} \beta$-NAD ${ }^{+} ; 0.2 \mathrm{mg}$ PMS : $0.4 \mathrm{mg} \mathrm{MTT;} 0.1 \mathrm{ml}$ of $0.5 \mathrm{M} \mathrm{MgCl}_{2}$.

Hexokinase $(\mathrm{HK}): \mathrm{l} \mathrm{ml}$ of Tris $\mathrm{HCl}, p \mathrm{H} 8 \cdot 6,0 \cdot 1 \mathrm{~m} ; 2 \mathrm{mg}$ glucose; $4 \mathrm{mg}$ $\beta$-NADP ${ }^{+}$; $1 \mathrm{mg}$ ATP; $0.2 \mathrm{mg}$ PMS ; 0.4 mg MTT; 10 units glucose-6phosphate dehydrogenase; $0.1 \mathrm{ml}$ of $0.5 \mathrm{M} \mathrm{MgCl}_{2}$.

Hydroxybutyrate dehydrogenase $(\mathrm{HBDH}): 1 \mathrm{ml}$ of phosphate buffer, $p \mathrm{H} \mathrm{7.4,0.5} \mathrm{\textrm { } : 1 \mathrm { mg } \mathrm { D } , \mathrm { L } - h y d r o x y b u t y r i c}$ acid; $1 \mathrm{mg} \beta-\mathrm{NAD}^{+} ; 3 \mathrm{mg}$ $\mathrm{NaCl} ; 0.2 \mathrm{mg}$ PMS; $0.4 \mathrm{mg} \mathrm{MTT} ; 0.1 \mathrm{ml}$ of $0.5 \mathrm{M} \mathrm{MgCl}_{2}$.

Isocitrate dehydrogenase (ICDH) $: 1 \mathrm{ml}$ of Tris $\mathrm{HCl}, p \mathrm{H} 8 \cdot 0,0.1 \mathrm{~m} ; 2.5 \mathrm{mg}$ $\mathrm{Na}$ isocitrate; $1 \mathrm{mg} \beta$-NADP+; $0.2 \mathrm{mg}$ PMS; $0.4 \mathrm{mg} \mathrm{MTT} ; 0.1 \mathrm{ml}$ of $5 \mathrm{~mm} \mathrm{McCl}_{2}$.

Malate dehydrogenase $(\mathrm{MDH}): 1 \mathrm{ml}$ of Tris $\mathrm{HCl}, p \mathrm{H} 8.0,0.1 \mathrm{~m} ; 2.5 \mathrm{mg}$ malic acid; $1 \mathrm{mg} \beta-\mathrm{NAD}^{+} ; 0.2 \mathrm{mg}$ PMS ; $0.4 \mathrm{mg}$ MTT.

Malic enzyme (ME). Identical to above procedure except that $\beta$-NAD ${ }^{+}$ is replaced with $\beta$-NADP+.

NADH diaphorase (DIA): $1 \mathrm{ml}$ of Tris HCl, $p \mathrm{H} 8 \cdot 6,0 \cdot 1 \mathrm{~m} ; 1 \mathrm{mg} \mathrm{NADH}$; $1 \mathrm{mg} \mathrm{2,6-dichlorophenol-indophenol;} 0.4 \mathrm{mg} \mathrm{MTT}$.

Phosphoglucomutase (PGM) : l ml of Tris HCl, $p \mathrm{H} 8 \cdot 0,0 \cdot 1 \mathrm{~m} ; 2 \mathrm{mg}$ glucose1-phosphate; $0.2 \mathrm{mg}$ glucose-1,6-diphosphate; $4 \mathrm{mg} \beta$-NADP+; $0.2 \mathrm{mg}$ PMS; $0.4 \mathrm{mg} \mathrm{MTT;} 10$ units glucose-6-phosphate dehydrogenase; $0.1 \mathrm{ml}$ of $0.5 \mathrm{M} \mathrm{MgCl}_{2}$.

Phosphoglucose isomerase (PGI): $1 \mathrm{ml}$ of Tris $\mathrm{HCl}, p \mathrm{H} 8 \cdot 6,0 \cdot 1 \mathrm{~m} ; 2.5 \mathrm{mg}$ fructose-6-phosphate; $1 \mathrm{mg} \beta$-NADP + ; $0.2 \mathrm{mg}$ PMS ; 0.4 mg MTT; 10 units glucose-6-phosphate dehydrogenase.

3-Phosphoglycerate kinase (3PGK): l ml of Tris $\mathrm{HCl}, p \mathrm{H} 8.0 ; 0.1 \mathrm{~m}$; $2.5 \mathrm{mg}$ of 3-phosphoglycerate; $1 \mathrm{mg} \mathrm{NADH} ; 1 \mathrm{mg}$ ATP; 4 units of glyceraldehyde-3-phosphate dehydrogenase; $0.1 \mathrm{ml}$ of $0.5 \mathrm{M} \mathrm{MgCl}_{2}$; $0.1 \mathrm{ml}$ of 10 per cent EDTA. Visualise as for GOT and GPT. 